\title{
Podpisana \\ i przypieczętowana. Apoteoza umowy w purytańskiej teologii federalnej
}

DOI: $10.35757 /$ CIV.2010.12.08

\section{Federaliści}

Nowoangielska szkoła teologii federalnej to przypadek purytanów, którzy politycznie sympatyzowali $z$ partia parlamentarna $\mathrm{w}$ jej sporze $z$ Korona toczonym w pierwszej ćwierci wieku XVII, w kwestii zaś ustroju kościelnego byli goracymi zwolennikami kongregacjonizmu. $Z$ jednej strony byli to przedsiębiorczy ludzie interesu, którzy zainwestowali swe środki w zamorskie kompanie handlowe. $Z$ drugiej - byli to żarliwi purytanie, Anglicy Pana Boga, którzy w plantacjach Nowego Świata pragnęli nade wszystko dobić $z$ Bogiem targu i zbawić swoje dusze. Nie przypadkiem zatem teologie wykładali w najporęczniejszej dla nich retoryce prawniczej i handlowej zarazem ${ }^{1}$.

Angielski termin „teologia federalna” (federal theology lub covenant theology) wywodzi się od łacińskiego foedus czy confoederatio

Nina Gtadziuk - doktor habilitowany, docent w Instytucie Studiów Politycznych Polskiej Akademii Nauk w Warszawie. Autorka Cóż po Grekach? Archetyp polis w twórczości Hannah Arendt (1991), Omphalos, czyli pępek świata. Płeć jako problem filozofii politycznej Greków (1997), Druga Babel. Antynomie siedemnastowiecznej angielskiej myśli politycznej (2005).

1 Do nawybitniejszych głosicieli teologii federalnej w Nowej Anglii należeli: John Preston, John Cotton, John Davenport, Richard Sibbes, Thomas Goodwin i Thomas Hooker. 
bądź od angielskiego covenant, z których wszystkie to odpowiedniki hebrajskiego berit - starotestamentowego pojęcia oznaczającego związek, umowę, ugodę, układ, pakt, sojusz, ligę lub przymierze. Przymierze, tak jak pojawia się w Biblii, reprezentuje całą gamę znaczeń. W Torze berit to umowa zawarta przez Boga $z$ Noem, Abrahamem i na koniec - za pośrednictwem Mojżesza - z ludem Izraela. Ewangelia przynosi dodatkowy sens przymierza jako testamentum - przymierza ufundowanego i wypełnionego przez Chrystusa. Kategoria przymierza zyskała na znaczeniu w dogmatyce okresu reformacji. Luter włączył ja do chrystologii, Kalwin natomiast uczynił $z$ niej element nauki o predestynacji. Za Kalwinem poszli anglosascy purytanie. Cały rozdział siódmy Westminsterskiego Wyznania Wiary (1646) poświęcony jest zbawczemu wymiarowi przymierza ${ }^{2}$.

Wedle Kalwina na mocy przedwiecznych dekretów Bożej woli wszyscy ludzie wybrani zostali do zbawienia bądź skazani na potępienie. W zakresie predestynacji Boże decyzje noszą charakter dekretów całkowicie arbitralnych. Jednych Bóg do wiary uzdatnia, a tym samym otwiera im droge do nieba, innych przeciwko wierze zatwardza, a tym samym droge do nieba zamyka. Dlatego też dramatyczna w swych moralnych konkluzjach Kalwińska nauka o predestynacji pozostawała oszczędna w wykładzie teologicznym. Skoro bowiem Boża wola to niczym nieograniczone liberum arbitrium, stanowione przez nią decyzje musza pozostać nieprzeniknione dla ludzkich umysłów. I dlatego Kalwin przestrzegał: „Przede wszystkim więc niechaj pamiętają, że badając kwestię predestynacji, wstępuja do tajemnych przybytków boskiej mądrości, których próg jeśli ktoś zbyt śmiało i pewnie przestapi, nie tylko nie zaspokoi swej ciekawości, lecz znajdzie się w labiryncie, z którego nie ma żadnego wyjścia”’3.

2 Por. Z. Pasek (red.): Wyznania wiary protestantyzmu, przekład zbiorowy, Instytut Religioznawstwa Uniwersytetu Jagiellońskiego, Kraków 1995, s. 64-65.

3 J. Kalwin: Nauka religii chrześcijańskiej, przekład I. Lichońska, w: Myśl filozoficzno-religijna reformacji XVI wieku, opr. L. Szczucki, Państwowe Wydawnictwo Naukowe, Warszawa 1972, rozdz. 21, ks. III, s. 375. 
Za paradoks historii myśli religijnej należy zatem uznać fakt, iż to purytańska teologia federalna - kalwińskiej wszak proweniencji - znalazła drogę wyjścia $z$ myślowych labiryntów, przed jakimi wymownie przestrzegał swego czasu Kalwin. W pismach nowoangielskich federalistów, dzięki uczynieniu $z$ kategorii przymierza „rusztowania i szkieletu dla całej konstrukcji teologii”, arbitralne dekrety Bożej woli stały się inteligibilne, uzyskały bowiem jurydyczną czytelność ${ }^{4}$.

$\mathrm{Za}$ ojca, a zarazem najbardziej wpływowego autora w obrębie szkoły purytańskiej teologii federalnej uznaje się Williama Amesa i jego traktat Medulla Sacrae Theologiae (1623). Niektórzy z teologów głosili „federalizm” jeszcze w Anglii, przed wielka migracja purytanów za ocean. Ale to dopiero federaliści Nowej Anglii wyciągnęli $z$ doktryny przymierza ostateczne konsekwencje teologiczne. Niektórzy z nich, już jako osadnicy w Nowej Anglii, popularyzowali ideę federalna w Anglii starej. Dobrze ilustruje to przypadek Johna Cottona (1584-1652), który niedługo po przybyciu do kolonii Massachusetts (w 1633 roku) okrzyknięty został jej czołowym teologiem. Lektura pism Cottona wyraźnie wpłynęła na Johna Owena, kapelana Olivera Cromwella, przyczyniajac się tym samym do wzrostu popularności idei kongregacyjnego ustroju kościelnego w szeregach Armii Nowego Wzoru. Odpowiednikiem tego, co w Nowej Anglii nosiło miano kościoła kongregacyjnego był na Wyspach Brytyjskich tak zwany kościół independencki (independency). Tak oto federalna teologia Nowej Anglii instruowała Anglię stara w kwestii rewolucyjnej idei Kościoła powstałego dzięki umowie. Wedle tej rewolucyjnej idei każda kongregacja ustanowiona przez nawróconych, którzy się zgromadzili, pozostaje w pełni autonomiczna. W doczesnych ramach Kościoła „widzialnego” nie istnieje żadna wyższa od niej władza eklezjalna. Ponieważ urzędy pastorów, nauczycieli, starszyzny i diakonów obsadzane były w drodze demokratycznego głosowania wszystkich członków kongregacji, ta ostat-

\footnotetext{
4 Por. P. Miller: Errand into the Wilderness, Harvard University Press, Cambridge 1970, s. 60.
} 
nia zdefiniowana być mogła jako wspólnota „bez papieża, prałatów, prezbitrów, księcia lub parlamentu".

\section{Umowa zbawcza}

Wedle purytańskich federalistów jedyna relacja, poprzez jaka Bóg kiedykolwiek wchodził $\mathrm{w}$ relację $\mathrm{z}$ człowiekiem była relacja federalna, czyli relacja przymierza. Wkrótce po stworzeniu pierwszego człowieka Stwórca zaproponował mu pakt: w zamian za posłuszne wypełnianie Bożego Prawa, Adam i jego potomstwo nagrodzeni być mieli życiem wiecznym. Owa pierwsza umowę, zwana Przymierzem Uczynków, Adam złamał i dlatego sprawiedliwie skazany został, a przez niego cała ludzkość, na śmiertelność.

Nauczony tym, że człowiek niezdolny jest sam $z$ siebie do wypełnienia Przymierza Uczynków, Bóg postanowił zawrzeć $z$ nim nowy pakt. Tym razem jako federalnemu reprezentantowi ludzkości zaoferował je Abrahamowi. W odróżnieniu od wcześniejszego Przymierza Uczynków, nowe Przymierze Łaski zmieniło warunki umowy zbawczej. To nie zgodne $z$ nakazami Prawa, zewnętrzne uczynki, ale wewnętrzna wiara w Boga stanowiły odtąd tę część umowy, z której człowiek musiał się wywiazać. Abraham miał wierzyć w nadejście Chrystusa jako Pośrednika i Odkupiciela. Po Chrystusie człowiek ma wierzyć, iż Pośrednik i Odkupiciel przyszedł, a Bogu uiszczone zostało „poręczenie”. W zasadzie jednak wszyscy nawróceni pozostają strona wciąż tego samego Przymierza Łaski. Nie przypadkiem zatem rozdział siedemnasty Księgi Genesis, opisujacy zawarcie Bożego przymierza $z$ Abrahamem, uzyskał na gruncie purytańskiej teologii federalnej rangę kluczowego ustępu Pisma Świętego.

Przymierze Laski - utrzymywali federaliści - stanowi umowę łatwiejsza do wypełnienia przez człowieka niż pakt zawarty jeszcze w ogrodzie Edenu. W wypadku Przymierza Uczynków człowiek zdany był na własne siły, czyli - w istocie - na własna niemożność. W wypadku Przymierza Łaski Bóg nie tylko zobowiązał się zbawić 
tych, którzy wierza, ale i dostarczyć im uzdatniającej do tego Łaski. Człowiek jako kontrahent umowy zbawczej nie jest już zdany wyłącznie na siebie. U podstaw zawartego $z$ człowiekiem Przymierza Łaski leży tajemnicza umowa, jaka Bóg zawarł był z Sobą Samym. Przymierze Odkupienia to umowa zawarta poza czasem pomiędzy Bogiem ojcem a Bogiem synem, a zarazem między Bogiem a ludzkością. Bóg Ojciec zesłał Syna, aby poniósł niezasłużoną śmierć $\mathrm{w}$ imię tych, których reprezentantem pozostaje w Przymierzu Odkupienia. Gdy federalnym reprezentantem ludzkości w Przymierzu Łaski pozostaje Abraham, federalnym reprezentantem ludzkości w Przymierzu Odkupienia pozostaje Chrystus. To w tym złożonym sensie powiada się, że Chrystus stał się Pośrednikiem, Odkupicielem i Poręczycielem (surety) w Przymierzu Łaski.

Im większy nacisk federalni teologowie kładli na jurydyczny aspekt Przymierza Łaski, tym bardziej odchodzili od Kalwińskiego rozumienia Boga jako Absolutnego Pana nad rodzajem ludzkim. Jądro Kalwińskiej teologii stanowi przekonanie o nieodgadnionej i bezwzględnie arbitralnej Bożej woli, której nikt i nic nie może ograniczać. $Z$ racji swych kreatorskich uprawnień Stwórca nie pozostaje w relacji jakiejkolwiek powinności wobec istoty przez siebie stworzonej: może ja ignorować, porzucić, a nawet zniszczyć. To dlatego wedle Kalwina Łaska, która staje się udziałem wybranych, pozostaje zawsze całkowicie nieprzewidywalna i całkowicie niezasłużona. Federaliści podzielali Kalwińskie przekonanie, iż wola Boża jako taka zawsze stanowić będzie dla człowieka niezgłębioną tajemnicę. W odróżnieniu od Kalwina utrzymywali jednak, że w tym zakresie, w jakim Przymierze Łaski stanowi umowę, wola Boża została w nim wyraźnie objawiona. Zdecydowawszy się na umowę $z$ człowiekiem, Bóg przestał być nieprzenikniona dla ludzkiego umysłu transcendencja, stał się bowiem Kontraktorem czy też - jak mówiono - Konfederatorem. Jako umowa Przymierze Łaski nie jest ani arbitralnym dekretem elekcji, ani miłosierna obietnica, reprezentuje bowiem klarowne, bo jurydyczne warunki zbawienia. W ten to sposób federaliści godzili arbitralność Boga 
jako Predestynatora $z$ niearbitralnością Boga jako Konfederatora. Jako Stwórca Bóg może dowolnie jednych wyznaczać do zbawienia, innych zaś skazywać na potępienie, ale w momencie zawarcia $z$ człowiekiem kontraktu zobligowany jest postępować zgodnie $z$ jego klauzulami: „Związek $z$ Bogiem nie jest tortura niepewności, nie jest porwaniem zaskoczonej duszy przez nieodparta łaskę, nieoczekiwana i niezasłużona, ale stanowi definitywny stan prawny [definite legal status]"'. Fakt, iż Bóg porozumiewa się z człowiekiem tylko w formie umowy rzuca światło na zgoła niearbitralny, a wręcz precyzyjny charakter Bożej woli. Nie przypadkiem purytanów zwano również „precyzjanami” (precisionists), bo konfederowali $z$ „precyzyjnym” Bogiem ${ }^{6}$.

Z Kalwińskiego punktu widzenia mówienie o Bożej umowie $z$ człowiekiem to bajdurzenie o umowie pyłu $z$ Wszechmogacym, tak bardzo stworzenie i Stwórca sa sobie nierówni. Przyznając, iż człowieka od Boga oddziela nieskończona przepaść, teologowie federalni wskazywali jednak na fakt jurydycznej równości, w jakiej zawsze pozostaja wobec siebie strony kontraktu. Po kalwińsku John Preston daje wyraz zasadniczej asymetrii Boga i człowieka: „On jest $\mathrm{w}$ niebiesiech, my jesteśmy na ziemi; on jest pełnym chwały Bogiem, my jeno pyłem i prochem; on jest Stwórca, a my zaledwie stworzeniami [...]", ale już jako federalista konkluduje, iż fakt Przymierza musi zakładać pomiędzy Bogiem a człowiekiem „rodzaj równości”’

Z Kalwińskiego punktu widzenia Bóg pozostaje arbitralny $\mathrm{w}$ swoich decyzjach zbawczych. Zgadzając się $z$ Kalwinem, iż człowiek nigdy nie przeniknie transcendentnej głębi Bożej Woli, federaliści argumentowali jednak, że obie strony Przymierza pozostaja kon-federatorami. Prefix kon- oznacza, że Bóg ponosi z człowiekiem współ-odpowiedzialność za wypełnienie zawartego paktu.

\footnotetext{
Ibidem, s. 71

${ }^{6}$ Por. P. Staples: Patterns of Purification: The New England Puritans, w: W.E.A. van Beek (red.): The Quest for Purity. Dynamics of Puritan Movements, Mouton de Gruyter, Amsterdam 1988.

7 Cyt. za P. Miller: Errand..., s. 64.
} 
Z moralnego punktu widzenia każda ze stron Przymierza winna jest drugiej pewne zobowiązania, przez co staje się jej dłużnikiem. W duchu tejże logiki należy rozumieć eksklamację Johna Prestona nad miłosierdziem Boga, który, będąc „pełnym chwały Panem Nieba i Ziemi, zgodzi się zawrzeć Przymierze, będzie układać się $z$ nami, jak gdyby gotów był siebie samego czynić naszym dłużnikiem"s.

\section{Teologiczny legalizm}

Przymierze (covenant) - centralne pojęcie siedemnastowiecznej teologii federalnej - używane było wymiennie $z$ wyrażeniami takimi jak compact, league, contract, agreement czy bond. W pisarstwie Nowoanglików, zwłaszcza zaś w kaznodziejskich kręgach Johna Prestona - zauważa Perry Miller - słowo „przymierze” (covenant) otrzymało uporczywie powracająca konotacje „[...] dobicia targu, kontraktu, wzajemnej ugody, dokumentu wiążacego obu sygnatariuszy, podpisanego $\mathrm{w}$ obecności świadków i przypieczętowanego przez notariusza publicznego"9. Oferta zbawcza przedłożona przez Boga w Przymierzu Łaski to ani obietnica, ani dar, ale zobowiązanie prawne. W ten sposób nowoangielscy federaliści posługiwali się szczególna, nie spotykana w żadnej innej odmianie religii reformowanej „legalistyczna teoria Boga dostarczającego człowiekowi podpisane i przypieczętowane zobowiązanie [signed and sealed bond]"10.

Teologiczny legalizm pozwolił im o grzechu pierworodnym mówić przez analogię do niespłaconej należności, która $z$ tytułu umowy przechodzi na potomków dłużnika. W ujęciu federalnym grzech pierworodny przestał być nieusuwalnym skażeniem, czy też zepsuciem ludzkiej natury, a stał się ciążąca na człowieku,

\footnotetext{
Ibidem.

9 Ibidem, s. 60.

${ }^{10}$ Ibidem, s. 62.
} 
bo odziedziczona po Adamie, „odpowiedzialnościa prawna”" ${ }^{\text {. Po- }}$ dobnie dziedziczony był ludzki „dług wobec Prawa”. Co prawda, wraz z Przymierzem Łaski to nie uczynki, ale wiara stanowiły teraz warunek zbawienia. Nie oznacza to jednak, że człowiek zwolniony został $z$ wypełniania prawa moralnego, które do Przymierza Łaski zostało włączone nie jako warunek zbawienia, ale „reguła słuszności" ${ }^{\prime 2}$. Dla zobrazowania tego federaliści przywoływali metafory komercyjne: kredytobiorca winien jest spłaty długu, mimo że brak mu pieniędzy. Podobnie człowiek winien jest Bogu wypełnianie nakazów prawa, mimo że brak mu do tego zdolności. Jako konfederator Przymierza Łaski człowiek zyskuje szansę na spłatę najstarszego długu wobec Prawa dzięki pośrednictwu Chrystusa jako konfederatora Przymierza Odkupienia. W Westminsterskim Wyznaniu Wiary Chrystus zwany jest nie tylko „testatorem” i „odkupicielem”, ale także „poręczycielem” (surety) ${ }^{13}$. Jako Odkupiciel Chrystus „odkupił” od Boga ludzki „dług” w postaci grzechu, jako Poręczyciel „zapłacił” zań „cenę” i tym samym poręczył Przymierze Łaski. Najdroższa dla człowieka transakcja zbawienia to na gruncie teologii federalnej skomplikowany ciag umów polegajacych na zaciaganiu długów, odkupywaniu ich i spłacie zadłużenia, na ciagu poręczeń, gwarancji oraz uiszczeń tego, co należne.

Teologia federalna wyłożona w legalistycznym idiomie pozwalała na śmiała koncepcję odpowiedzialności prawnej, jaka spoczywa nie tylko na człowieku, ale i na samym Bogu. Człowiek odpowiedzialny jest za tę część umowy, jaką wziął na siebie, czyli zadośćuczynienie wierze, Bóg odpowiedzialny jest za tę część umowy, jaka wział na siebie, czyli za zbawienie ludzkiej duszy. Wymiana zbawienia za wiarę stanowi treść umowy zbawczej właśnie. Jeżeli człowiek dopełni swojej części Przymierza, Bóg nie może być jego naruszycielem (covenant-breaker), musi dotrzymać danego słowa:

\footnotetext{
${ }^{11}$ Por. ibidem, s. 81.

${ }^{12}$ Por. P. Miller: The New England Mind. The Seventeenth Century, Harvard University Press, Cambridge 1971 , s. 384.

${ }^{13}$ Por. Z. Pasek (red.): Wyznania wiary..., s. 65-66.
} 
„Przymierze łaski określa warunki, pod którymi można dostąpić Niebios, i ten, kto wypełni te warunki, posiada bezsporny tytuł do chwały, dokładnie tak jak ten, kto płacąc ogłoszoną cenę, wchodzi w posiadanie własności" ${ }^{14}$.

$Z$ legalistycznego punktu widzenia jeżeli człowiek dopełni warunków przymierza Łaski, to zbawienie jest czymś, co mu się należy, bo tak stanowi umowa. „Bóg może długo $z$ tym zwlekać, ale - przekonuje John Preston - uczyni to, bo nie ma wyboru, bo stanowi to Jego część Przymierza"15. Zadośćuczyniwszy swojej części kontraktu zbawczego, człowiek ma prawo wezwać druga stronę do rozrachunku. Preston nie zawaha się zatem powiedzieć, iż człowiek wierzacy samego Boga może „[...] pozwać względem Jego własnego zobowiazania, spisanego i przypieczętowanego, a On nie może mu zaprzeczyć"16.

Przymierze Łaski jest nie tylko umowa, ale także transakcja wymienną: człowiek winien jest Bogu wiarę, Bóg winien jest wierzacemu zbawienie. Jest to rodzaj wyraźnie sformułowanej transakcji, polegajaccej na quid pro quo, na " "jeżeli wierzę" prowadzącym z konieczności do "musisz mnie zbawić"”" Nowoangielska teologia federalna stanowi szczególny przypadek w historii idei, jedynie bowiem na jej gruncie relacja człowieka $z$ Bogiem staje się relacja przywodząca na myśl stosunek, w jakim pozostaja „dwaj partnerzy w przedsięwzięciu biznesowym" ${ }^{18}$.

Specyficzny prawniczo-handlowy duch wypełnia i samą kongregację. Podstawowym jej celem jest dostarczenie środków do zawierania i dotrzymywania Przymierza $z$ Bogiem. To dlatego centrum kongregacji jako instytucji duszpasterskiej stanowi nie sakramentalny ołtarz, ale kaznodziejska kazalnica. Głoszone $z$ niej Słowo to $\mathrm{w}$ istocie ciagłe propagowane Przymierze Łaski. W tym dopiero kontekście zrozumieć można egzortę purytańskich pastorów

\footnotetext{
14 P. Miller: Errand..., s. 60

15 Cyt. za ibidem, s. 72.

16 „You may sue him of his own bond written and sealed, and he cannot deny it”. Ibidem.

17 Ibidem, s. 71.

18 Ibidem, s. 60-61.
} 
wzywających audytorium do bycia przedsiębiorczym, do bycia gotowym, by zawrzeć umowę ze Stwórca i ocalić swoją duszę. Poddanie się kaznodziejskiej perswazji rozumiane było - zauważa Miller - jako „okazja dobicia targu, szansa uczynienia ważnego kroku, okazja, która za pośrednictwem duszpasterskiej posługi nadarza się w szczególnym momencie. Jeżeli jednostka, mając szansę, nie domyka transakcji, to o jej stratę $z$ pewnościa nie może obwiniać Boga"19.

Skoro Przymierze $z$ Bogiem człowiek zawsze zawiera w swojej jednostkowości, to do czego potrzebny mu jest Kościół? Otóż kongregacja niezbędna jest $\mathrm{w}$ tym sensie, iż zapewnia obecność współparafian jako świadków. To oni moga zaświadczyć, że nawrócony daje widome znaki bycia pod wpływem Bożej łaski i gotów jest kroczyć ścieżkami Pana. Kongregacja dostarcza forum, na którym wierny może publicznie podjać się zobowiązań, jakie nakłada nań Przymierze. Kongregacja odgrywa zatem rolę swoistej Bożej kancelarii, w jakiej umowa zbawcza zostaje poświadczona i zaprzysiężona. To dlatego w kościele kongregacyjnym przystapić do Wieczerzy Pańskiej nie moga wszyscy bez wyjątku wierni, ale jedynie widzialni „święci”, czyli konfederatorzy. Uczestnictwo w Wieczerzy Pańskiej nie stanowi bowiem dostępu do zbawczego sakramentu, ale legalistyczny znak i pieczęć (seal) pozostawania w Przymierzu z Bogiem ${ }^{20}$.

\section{Uświęcenie umowy}

Jeszcze św. Augustyn wydrwiwał tych, którzy w umowie społecznej doszukiwali się podstawy państwa sprawiedliwego. „Bo i banda jest małym królestwem - zauważał sarkastycznie. Tam przecież szajka ludzi także podlega rządom dowódcy, jest skrępowana umowa społeczna i podług pewnych praw umówionych

19 Ibidem, s. 86

${ }^{20}$ Por. Z. Pasek (red.): Wyznania wiary..., s. 80. 
dzieli się zdobycza" 21 . Kontraktualizm, tak stanowczo zdezauowany na kartach Państwa Bożego, nieoczekiwane triumfy odnosić zaczął $\mathrm{w}$ pismach siedemnastowiecznych teologów federalnych. W oczach tych ostatnich wykładanie Przymierza kaski poprzez schemat kontraktu bynajmniej nie stanowiło bluźnierstwa i uwłaczania Bożej wszechmocy. Na odwrót, uznawano, że skoro sam niczym nieograniczony Bóg postanowił ułożyć się $z$ człowiekiem $\mathrm{w}$ formie przymierza, skoro sam zobowiąał się postępować lege artis, to tym samym dał wyraźnie do zrozumienia, iż upodobał sobie sprawiedliwość rozumiana kontraktualnie. Pamiętajmy bowiem, że przymierze to szczególna, wyróżniona relacja, w jaka Bóg postanowił wejść nie tylko $z$ człowiekiem, ale $i$ z Soba Samym.

W momencie, gdy Bóg dostarcza wzniosłego wzorca sprawiedliwego Konfederatora, również istota ludzka, stworzona na obraz i podobieństwo Boże, może być rozumiana nade wszystko jako istota zdolna do zawarcia umowy i dotrzymania jej. W ten sposób nie tylko obraz człowieka jako kontraktora, ale i wspólnota powstała w drodze społecznej umowy dostępuja - niepojętej na gruncie myśli Augustyńskiej - teologicznej nobilitacji. Te spośród ludzkich związków, które - jak małżeństwo, kongregacja wiernych, ciało polityczne czy kompania handlowa - powołuje do życia dobrowolna umowa jednostek, uznane zostaja za szczególnie miłe Bogu i namaszczone Jego błogosławieństwem.

Nic nie uświęca maksymy pacta sunt servanda bardziej niż teologiczne ujęcie Boga jako Wielkiego Konfederatora zawierającego z człowiekiem umowę zbawczą: spisana, podpisana i przypieczętowana. Relacja ta stanowi wzorzec wzajemnego zaufania, jakim winni się darzyć kontrahenci ludzkich umów. Pozwala to związek zadzierzgnięty na podstawie umowy traktować jako najmocniej pod względem moralnym wiążący. W wypadku przymierza, tak jak rozumieli je federaliści - wyjaśnia Perry Miller - człowiek „pozostaje

\footnotetext{
${ }^{21}$ Św. Augustyn: Państwo Boże, przekład ks. W. Kubicki, Wydawnictwo Antyk, Kęty 1998.
} 
nieskończenie bardziej dłużny niż w wypadku obietnicy, bardziej zobowiązany niż w wypadku prawa, bardziej zaangażowany niż w wypadku testamentu, bardziej odpowiedzialny niż w wypadku przysięgi”22.

Skupiwszy się na moralnym wymiarze umowy, nowoangielscy purytanie kreślili dystynkcję między wolnością "naturalną" a „federalna”, zwana też „cywilna”. Klasycznego w tym względzie sformułowania dostarcza słynna mowa Johna Winthropa skierowana do Sądu Ogólnego $z$ roku 1645. W wypadku wolności naturalnej, którą człowiek dzieli ze zwierzętami, dysponuje on „swoboda czynienia wszystkiego, co mu się żywnie podoba; jest to wolność czynienia tyleż zła, co i dobra". To dlatego - dowodził gubernator - wolność naturalna nie może „ścierpieć najsłabszych więzów najsprawiedliwszej władzy". W przeciwieństwie do anarchizmu wolności naturalnej, wolność „cywilna” lub „federalna”, nazwana tak „W nawiązaniu do przymierza zawartego pomiędzy Bogiem i człowiekiem [...] a także politycznych przymierzy i konstytucji, zawieranych pomiędzy samymi ludźmi”, nie tylko nie kontestuje władzy, ale stanowi jej podstawowy cel. Wolność federalna jest bowiem wolnością „czynienia tylko tego, co dobre, sprawiedliwe i uczciwe"23. Nikt nie może być przymuszony do tego, by zawrzeć umowę. W momencie jednak, gdy do niej dobrowolnie przystapił, wybrał powinność czynienia tego, do czego się umowa zobligował. Wolność naturalna umożliwia sam akt zawarcia umowy, ale dokonanie tego aktu równoznaczne jest $z$ porzuceniem wolności naturalnej na rzecz federalnej, albo ściślej rzecz biorąc: wolności na rzecz zobowiązania.

Kościół kongregacyjny reprezentował dla federalistów instytucję kontraktualna par excellence. Ponieważ do istnienia powoływała go zbiorowa decyzja zgromadzonych, Kościół taki nie różnił się od innych wspólnot dobrowolnych. Podobnie jak one stanowił on

\footnotetext{
${ }^{22}$ P. Miller: The New England Mind..., s. 375.

${ }^{23}$ J. Winthrop: Speech to General Court, w: P. Miller, T.H. Johnson: The Puritans, Harper Torchbooks, New York 1963, t. 2, s. 206-207.
} 
korporacje jednostek zjednoczonych dzięki umowie $\mathrm{w}$ jedno ciało. Jednak w akcie konfederacji powołującej kościół do istnienia nie mogli uczestniczyć wszyscy, ale jedynie „widzialni święci”. Odpowiednio też tylko nawróceni, czyli tacy, którzy dostarczyli naoczne świadectwo bycia w stanie Łaski, dostępowali pełnoprawnego w nim członkostwa. Kongregacja stanowiła zatem wspólnotę kontraktualną na dwóch poziomach konfederacji: ludzkim i boskim. Była zarówno wspólnota tych, którzy sprzymierzyli się pomiędzy sobą, jak i wspólnota tych, którzy zawarli przymierze $z$ Bogiem. Jako podmioty ludzkiej korporacji tylko oni mieli prawo decydować w kwestii członkostwa innych bądź wykluczenia ich z kościoła. Jako strony Przymierza Łaski tylko oni mieli prawo uczestniczyć w Wieczerzy Pańskiej przypieczętowującej umowę zbawczą z Bogiem.

\section{Federalna teoria polityczna}

W An Apology for Church Covenant (1643) bostoński teolog Richard Mather daje zarys federalnej teorii politycznej. Otóż istnieja relacje, które ukonstytuowane sa na podstawie umowy i takie, które umowy nie potrzebują: „Nie ma bowiem przymierza, które czyniłoby człowieka rodzicem lub dzieckiem" ${ }^{24}$. Podobnie do rodzinnych więzi „naturalnych”, dobrowolnie zawartego kontraktu nie wymagają również stosunki oparte na sile, jakie łączą zdobywcę $z$ podbitym przezeń ludem. Natomiast „wszystkie relacje dobrowolne - konkluduje autor - wszystkie relacje, które nie sa naturalne bądź zostały oparte na przemocy, musza być zadzierzgnięte w formie przymierza [covenant]"25. Na przymierzu zasadzaja się relacje między: mężem a żoną, panem a sługa, księciem a poddanymi,

\footnotetext{
${ }^{24}$ Za: A.S.P. Woodhouse (red.): Puritanism and Liberty, Being the Army Debates (1647-9) from the Clarke Manuscripts with Supplementary Documents, University of Chicago Press, Chicago 1951, s. 300.

${ }^{25}$ Ibidem.
} 
pastorem a wiernymi, cała kongregacja a jej nowymi członkami, partnerami $\mathrm{w}$ handlu czy wreszcie - sygnatariuszami paktu powołującego do życia nową rzeczpospolitą. Umowa pozostaje zatem jedynym sposobem konstytuowania wspólnot, stowarzyszeń dobrowolnych czy - jak to wówczas mówiono - korporacji. Wszystkie owe korporacje - jak kompania handlowa, samorząd miejski, państwo czy kongregacja kościelna - łączy fakt, że powołane zostały do życia przez jednostki „inkorporujace się" w jedno ciało zbiorowe poprzez akt umowy.

Wyłaniający się $z$ kart Kalwińskich Instytucji... obraz Boga jako absolutnego Pana rządzącego dekretami, u teologów federalnych ulega znamiennemu przeobrażeniu, dostarczając wzorca konstytucyjnie ograniczonego monarchy, który solennie przestrzega warunków zawartej przez siebie umowy ${ }^{26}$. Za główny paradoks teologii federalnej należy uznać przekonanie, iż Bóg, jako konfederator Przymierza Łaski, dobrowolnie ogranicza swą Wszechmoc i narzuca Sobie ryzy kontraktu. Skoro jednak sam Bóg ograniczony jest jurydycznymi warunkami umowy zawartej $z$ człowiekiem, to tym bardziej skrępowany umową $z$ poddanymi musi być każdy ziemski władca. W ten sposób idea samoograniczenia Boga jako Konfederatora wiodła nowoangielskich federalistów do konsekwentnego głoszenia politycznej doktryny władzy ograniczonej. „Konieczne jest - przekonywał John Cotton w kazaniu z 1656 roku - iżby cała władza, która jest na ziemi, pozostawała ograniczona; władza kościoła czy inna. [...]. Za niebezpieczne uznaje się, iżby państwo ograniczyło swe prerogatywy; ale większym niebezpieczeństwem jest, jeśli ich nie ograniczy"27.

Za główne maksymy purytańskiej teorii politycznej uznaje się zazwyczaj trzy następujące przekonania: (1) każda organizacja opiera się na dobrowolnym członkostwie; (2) każda władza ograniczona jest przez wyższe od niej prawo; (3) każda władza legitymizowana jest przez zgodę rządzonych. Nietrudno zauważyć,

${ }^{26}$ Por. P. Miller: Errand..., s. 91 (przypis).

27 J. Cotton: Limitation of Power, w: P. Miller, T.H. Johnson: The Puritans..., t. 1, s. 213. 
że dobrowolne członkostwo i zgoda rządzonych w federalnej teorii politycznej pozostaja skorelowane. Jednostkę nie obliguje bowiem nic, na co osobiście, bądź poprzez swych przedstawicieli, nie wyraziła zgody. W wypadku korporacji politycznej jednostki podporządkować się muszą tylko takiej formie rządu, która przedtem na mocy przymierza same ustanowiły. Analogicznie w wypadku korporacji duchowej: wierni winni sa posłuszeństwo tylko tym urzędnikom kościoła, których sami w drodze demokratycznego głosowania wybrali. Richard Mather w takim oto syntetycznym ujęciu czyni zasade zgody rządzonych kardynalnie ważną zarówno w organizacji rządu kościelnego, jak i władzy publicznej: „Wszyscy chrześcijanie mają władzę i prawo, iure divino, wybierania swoich własnych urzędników [officers], którym powierzaja swe dusze (Dz $6.1 ; 14 ; 23$ ). I tak jak maja prawo wybrać swoich urzędników, tak samo maja prawo wybrać swoich braci [brethren] zgodnie $z$ Bogiem (Rz 14.1). Skoro maja prawo wybrać swoich urzędników i braci, to nikt, bez ich własnej zgody, nie może nad nimi dzierżyć władzy, żadni urzędnicy i żadni bracia, których oni samodzielnie nie wybrali ani którym w formie przymierza czy zobowiązania nie obiecali być poddanymi w imię Pańskie"28.

W wyrażeniu wywiazywanie się $z$ umowy, którego wciąż używamy, pobrzmiewa ten sam stary sens, który federalna teologia czyniła moralnym jądrem swojej teorii społecznej i politycznej. Określenie wywiazać się $z$ umowy sugeruje, że dopiero gdy strony dopełniły umowy, ich więź wzajemna ulega rozwiązaniu. I na odwrót: tak długo, jak pozostaja w relacji kontraktu, sa ze sobą zwiazane. Język dobrze oddaje asymetryczność zajmującej nas tutaj metaforyki: zawieranie umowy to zwiazywanie sie nia, dopełnienie umowy to wywiazanie sie $z$ niej. Strony umowy zaciagaja wobec siebie zobowiazania i pociagaja sie tym samym do odpowiedzialności. Umowa stanowi wzajemnie przez kontrahentów zaciagnięty

${ }^{28}$ Za: A.S.P. Woodhouse (red.): Puritanism..., s. 300. 
węzeł powinności. Pod względem moralnym każda $z$ jej stron występuje wobec drugiej jak dłużnik wobec wierzyciela.

Sens łączenia i wiązania żywo obecny jest w angielskim synonimie umowy, jakim się siedemnastowieczni federaliści często posługiwali, czyli w bond. Słowo bond oznacza wiele rzeczy naraz: związanie się umowa, zobowiązanie dłużne, ale również związek, jednoczenie się czy połączenie razem (bonding, binding). Łacińska analogia tego ostatniego jest czasownik ligare: oznaczajacy czynność wiązania czy łączenia razem. $Z$ czasownikiem ligare spokrewniony jest czasownik obligare, oznaczajacy zobowiazywanie się. Tym, co angielskie słowo bond i $z$ łaciny pochodzaca obligacja maja wspólnego jest jednoczesne oznaczanie zobowiązania skarbowego, powinności moralnej i połączenia. Umowy zawierane pomiędzy ludźmi stanowią akty wzajemnego zaciągania długu, wzajemnego zobowiązywania się do jego uiszczenia, a jednocześnie akty związywania się razem. Umowa dlatego, że ob-liguje, tworzy ligę. Społeczność powstała dzięki umowie posiada najmocniejsza ligature, bo jest ona w pełni moralnej natury. W duchu tej to metaforyki o wspólnocie zadzierzgniętej dzięki umowie federaliści mówili, że jest „gęsto utkana”.

\section{Kontraktualizm w praktyce}

Wcześniej niż gdziekolwiek indziej koloniści angielscy w Ameryce realizowali zasadę wyboru ustroju poprzez umowę społeczna, a za podstawę władzy prawowitej uznawali zgodę rządzonych. „Kolonizacje w zasadzie przeprowadzały towarzystwa handlowe - zauważa historyk - tak typowe dla historii Anglii, o tej samej podstawie prawnej co "Spółka Wschodnio-Indyjska", będąca właścicielem Indyj aż do roku 1856. [...] Towarzystwa te otrzymywały od korony angielskiej tzw. charters, karty nadania ziemi, które między innymi dawały im prawo ustanawiania takiej formy rzadu, jaka im odpowiadała. Te karty-przywileje w postaci statutów 
i uchwał spółek to podstawa prawna i ustrojowa wielu $z$ pierwszych trzynastu stanów amerykańskich"29.

Pierwszy przypadek purytańskiego osadnictwa w Nowej Anglii to osada Plymouth założona na podstawie Mayflower Compact (1620) Dokument ten, podpisany na pokładzie statku Mayflower jeszcze przed przybiciem do portu w Plymouth (Massachusetts), wzywał pasażerów do podporządkowania się zarządzeniom samoukonstytuowanego Civil Body Politic. Warto w tym miejscu przytoczyć ciekawą okoliczność powstania tej pierwszej nowoangielskiej kolonii. Otóż Ojcowie Pielgrzymi, jak ich nazywa amerykańska historiografia, płynęli do Nowego Świata przekonani, że płyna do Wirginii, na osadnictwo w której otrzymali od króla patent. Zamiast tego wylądowali w Cape Cod. Wysiedli zatem na ląd pozostający poza autoryzowana jurysdykcja jakiejkolwiek innej kolonii, a więc poza jurysdykcja angielskiej władzy państwowej. W ten to sposób Przymierze $z$ Mayflower, które scaliło jego sygnatariuszy we wspólnotę polityczna i stało się fundamentem ustroju kolonii Plymouth, stanowi empiryczny przypadek ustanowienia państwa $\mathrm{w}$ warunkach tak zwanego stanu natury.

Drugi słynny przykład samorządu kolonialnego ustanowionego na podstawie umowy to przypadek Karty Zatoki Massachusetts (Charter of Massachusetts Bay) z 1629 roku. W tym wypadku The Massachusetts Bay Company (MBC), spółka akcyjna pierwotnie $z$ siedziba w Anglii, przeniosła się wraz z udziałowcami za ocean. Po osiedleniu się $\mathrm{w}$ Massachusetts, MBC $z$ kompanii handlowej została przekształcona w rzeczpospolitą, karta zaś spółki - w konstytucje kolonii.

Fakt, iż w wielu „plantacjach” Nowego Świata statuty kompanii handlowych przeformułowane zostały w polityczne konstytucje kolonii przesądził o triumfie myśli federalnej. W jednej spójnej teorii nowoangielscy federaliści połączyli zasadę spółki akcyjnej z zasada kolonialnego samorządu, a także zasadą kościoła kongregacyjne-

${ }^{29}$ P. Zaremba: Historia Stanów Zjednoczonych, Instytut Literacki, Paryż 1957. 
go. Mało kto dzisiaj pamięta tę teorię, ale ostała się organizacja społeczna, pewne dogmaty dotyczące wolnych instytucji i w ogóle cechy mentalne, które odcisnęły swe purytańskie piętno na amerykańskim charakterze. Za najważniejsze w tej mentalności uznać należy przekonanie, iż uczestnictwo we wspólnocie kontraktualnej (covenanted community) jest bardziej zobowiazujące moralnie niż przynależność oparta na dziedziczonym przywileju, tradycji czy związkach krwi. 